\title{
Morphometric analysis of the coronary arteries: a study of the external diameters
}

\author{
SILVA, J. M. L. ${ }^{1}$, NAGATO, A. C. ${ }^{1}$, REIS, R. B. ${ }^{1}$, NARDELI, C. R. ${ }^{1}$, \\ ABREU, F. P. ${ }^{2}$ and BEZERRA, F. S. ${ }^{2 *}$
${ }^{1}$ Laboratory of Biomorphology and Experimental Pathology, Center of Health Science, Universidade Severino Sombra - USS, Av. Expedicionário Osvaldo de Almeida Ramos, 280, Centro, CEP 27700-000, Vassouras, RJ, Brazil Campus Universitário Morro do Cruzeiro, s/n, Bauxita, CEP 35400-000, Ouro Preto, MG, Brazil
*E-mail: email: franksbezerra@hotmail.com \\ ${ }^{2}$ Human Anatomy Laboratory, Department of Biological Sciences, Universidade Federal de Ouro Preto - UFOP,
}

\begin{abstract}
Introduction: Approximately a third of worldwide deaths are caused by ischemic or coronary heart disease, suggesting that greater attention is needed to study the coronary diameter and myocardial vasculature. Material and Methods: In this study, 39 human adult hearts were dissected. The masses of the hearts were measured according to the principle of Scherle and the external diameters of the right coronary artery, the left coronary artery, and the ascending part of the Aorta were measured in millimeters ( $\mathrm{mm}$ ), using a Mitutoyo digital caliper. In the statistical analysis, normal distribution of the variables was assessed using the Kolmogorov-Smirnov test, external diameters were compared using the unpaired Student's t-test, and Pearson's correlation was applied to investigate the correlation of the diameters of the left coronary artery and right coronary artery with the Aorta. Significance was set at $P<0.05$, and the data were analyzed using GraphPad Prism v.5.00 (GraphPad Software, San Diego, CA). Results: The external diameters were as follows: left coronary artery, $5.55 \pm 0.16 \mathrm{~mm}$; right coronary artery, $4.38 \pm 0.15 \mathrm{~mm}(P<0.0001)$; and Aorta, $22.85 \pm 0.80 \mathrm{~mm}$. Thus, it was demonstrated that the external diameter of the left coronary artery is $22 \%$ larger than that of the right coronary artery, resulting in a greater blood supply via the left coronary artery and a greater passage of atherosclerotic factors. Conclusions: Despite the importance of the coronary arteries for the heart and the body as a whole, few studies correlated morphometric data and possible clinical implications related to coronary artery disease.
\end{abstract}

Keywords: aorta, heart, coronary artery.

\section{Introduction}

Cardiovascular disease (CVD) including coronary artery disease $(\mathrm{CAD})$, cerebrovascular disease, peripheral vascular disease, rheumatic heart disease, congenital heart disease, deep vein thrombosis, and pulmonary vascular disease, is a worldwide public health problem. Ischemic or coronary heart disease (CHD) is a leading cause of morbidity and mortality in both sexes (MYERS and MENDIS, 2014), resulting in approximately one third of worldwide deaths (WONG, 2014). In the United States (USA), CAD is the most common type of CVD, which predisposes an individual to a heart attack. Additionally, it is estimated that 1.1 million Americans suffer a major coronary adverse event, resulting in the death of about $34 \%$ of these individuals during 2014 , despite the availability of effective treatment strategies to reduce cardiovascular risk (GO, MOZAFFARIAN, ROGER et al., 2014). From 1990 to 2010 , there was a $35 \%$ increase in the number of deaths worldwide due to CHD (MYERS and MENDIS, 2014), and it is predicted that by 2030 , CHD will affect 23.3 million people, making it the greatest single cause of death. This situation requires special attention, as most individuals do not exhibit any symptoms or warning signs prior to coronary events such as acute coronary syndrome or sudden cardiac death (MAUROVICH-HORVAT, FERENCIK, VOROS et al., 2014).
Knowledge of the anatomy of the heart as well as the coronary arteries and the Aorta is important because the cardiovascular system is responsible for blood flow throughout the body. Cardiomyocytes depend on optimal blood supply to deliver oxygen and metabolic substrates to the body, as their contractile property results in a propulsion mechanism which aids the delivery of blood into the arteries and to the body (MADJID and FATEMI, 2013; YIN, HASSAN, HAROUN et al., 2014). Therefore, the coronary arteries that are responsible for supplying blood to the heart, should receive suitable blood for their morphological integrity. Additionally, they are significant for the clinical and surgical study of the heart (MCCULLOUGH, 2007).

Accordingly, further study of the diameter of the coronary arteries is required, since this is related to myocardial vascularization (TULLOH and WOOD, 2004). The difference between the outer diameters of the coronary arteries is still uncertain, as well as its correlation with the aortic diameter. Thus, the present study aimed to investigate the external diameter of the coronary arteries and the ascending part of the Aorta (AA), as well as investigate a correlation between these vessels. 


\section{Materials and Methods}

In this study, approved by Ethics Committee, 39 human adult hearts were dissected. The total mass of the samples was measured by Scherle's method (AGUILA, MANDARIMDE-LACERDA and APFEL, 1998), and the outer diameters of the right coronary artery (RCA), the left coronary artery (LCA) and the AA were measured in millimeters ( $\mathrm{mm})$, with the aid of Mitutoyo digital calipers. The external diameter of the RCA in superior medial view (Figure 1A) was measured first, followed by the external diameter of LCA in superolateral view (Figure $1 \mathrm{~B}$ ) and finally the external diameter of the AA in the upper anterior view (Figure 1C).

Data were expressed as mean \pm standard error of the mean, and the normal distribution of the variables was assessed using the Kolmogorov-Smirnov's test. Comparison of the external diameters was performed using the unpaired Student's t-test, and correlation between the diameters of the LCA and RCA with the diameter of AA was investigated according to Pearson's correlation. Significance was set at $P<0.05$ and the data evaluated by GraphPad Prism v.5.00 (GraphPad Software, San Diego, CA).

\section{Results}

Morphometric analysis found that the external diameter of the LCA $(5.55 \pm 0.16 \mathrm{~mm})$ was $22 \%$ greater than the external diameter of the RCA $(4.38 \pm 0.15 \mathrm{~mm})(p<0.0001)$ (Figure 2$)$. There was no correlation between the external diameter of the AA $(22.85 \pm 0.80 \mathrm{~mm})$ and the external diameter of the RCA $(4.38 \pm 0.15 \mathrm{~mm}),(\mathrm{r}=0.05, p=0.74)$ (Figure $3 \mathrm{~A})$. Similarly, the external diameter of the AA did not correlate with the external diameter of the LCA $(5.55 \pm 0.16 \mathrm{~mm})$, $(\mathrm{r}=0.12 ; p=0.53)$ (Figure $3 \mathrm{~B})$.

There was a moderate positive correlation between the total mass of the heart $(238.9 \pm 13.54 \mathrm{~g})$ and the external diameter of the LCA $(5.55 \pm 0.16 \mathrm{~mm} ; \mathrm{r}=0.35 ; p=0.04)$, (Figure 3C). However, there was no correlation between the total mass $(238.9 \pm 13.54 \mathrm{~g})$ and the external diameter of the RCA $(4.38 \pm 0.15 \mathrm{~mm} ; \mathrm{r}=0.25 ; p=0.15)$, (Figure 3D).

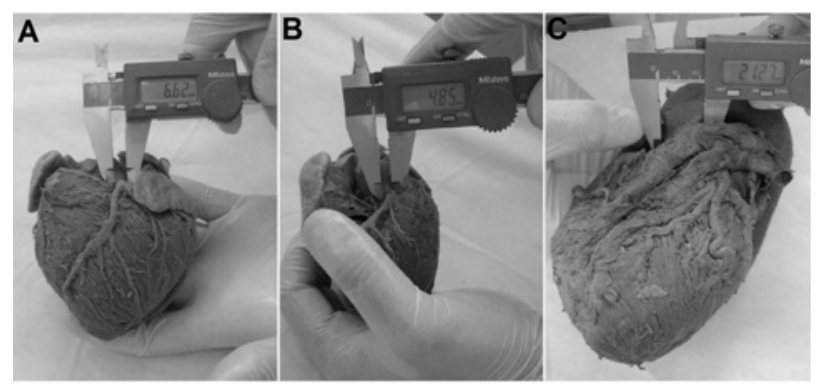

Figure 1. Measurement of the external diameters of arteries of human adult hearts. The measurement was analyzed in millimeters $(\mathrm{mm})$ with Mitutoyo digital pachymeter. The values were expressed as mean \pm standard error. (A) Measurement of the external diameter of the right coronary artery $(4.38 \pm 0.15 \mathrm{~mm})$, superior medial view. (B) Measurement of the external diameter of the left coronary artery $(5.55 \pm 0.16 \mathrm{~mm})$, superolateral view. (C) Measurement of the external diameter of the Aorta artery $(22.85 \pm 0.80 \mathrm{~mm})$, upper anterior view.
The coronary arteries (CAs) are the first branches of the Aorta, which supply blood to the myocardium (BEZERRA, NAGATO, VIEIRA et al., 2008). The clinical manifestations and cerebrovascular disease of CHD differ in magnitude from those of other CVDs (GO, MOZAFFARIAN, ROGER et al., 2014).

Atherosclerosis occurs due to the accumulation of fatty plaque within the CAs and is the most common cause of myocardial ischemia (NORIEGA, VIVES-BORRÁS, SOLÉ-GONZÁLEZ et al., 2014). Cardiovascular risk factors, such as hypertension, diabetes, and dyslipidemia may influence the development of atherosclerosis and thereby trigger CAD, resulting in myocardial damage and heart failure accompanied with a low ejection fraction of blood (TAYLOR and HOBBS, 2013). Over time, fatty plaque may harden or break, and treating this may cause plaque stenosis of CAs and thus reduce the flow of oxygen-rich blood to the heart. If there is rupture of an atheromatous plaque, a blood clot can form on the surface of the CA and thus reduce or block blood flow to the heart muscle. A lack of adequate blood supply to the heart can cause angina or myocardial infarction (MI) (TERESA ALBELDA, GARCIA-ESPANA and FRIAS, 2014).

The coronary arteries, often found in pairs, may vary in origin, distribution, number, and size (BEZERRA, NAGATO, VIEIRA et al., 2008). Nordon and Rodrigues Júnior (2012) in a study of 50 human hearts observed that the main variations of the LCA were hipoplastic (8\%) and 3 to 4 additional diagonal arteries (4\%); and the variation of the RCA was hipoplastic (2\%). Therefore, anatomical knowledge of these arteries is imperative for the maximum utilization of therapeutic techniques against $\mathrm{CHD}$. Improved attention to possible variations in the origin and course of the main CAs can considerably increase the clinical and surgical results as well as improve the diagnosis and treatment of CHD (LOUKAS, GROAT, KHANGURA et al., 2009). In a normal heart, the initial portion of the Aorta is occupied by the aortic sinuses, which are also known as Valsalva breasts (LOUKAS, GROAT, KHANGURA et al., 2009).

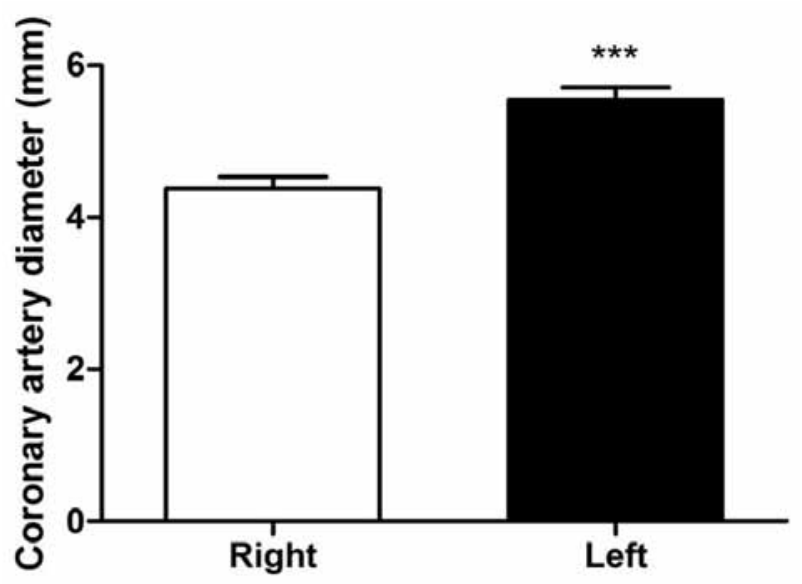

Figure 2. External diameters of right and left coronary arteries of dissected human adult hearts $(\mathrm{n}=39)$. Right coronary artery, Right - white bar $(4.38 \pm 0.15 \mathrm{~mm})$; Left coronary artery, Left - black bar $(5.55 \pm 0.16 \mathrm{~mm})$. The values were expressed as mean \pm standard error. ${ }^{* *}$ Means difference enters the Right and Left, with $p$-value $<0.0001$ at unpaired Student's t-test. 

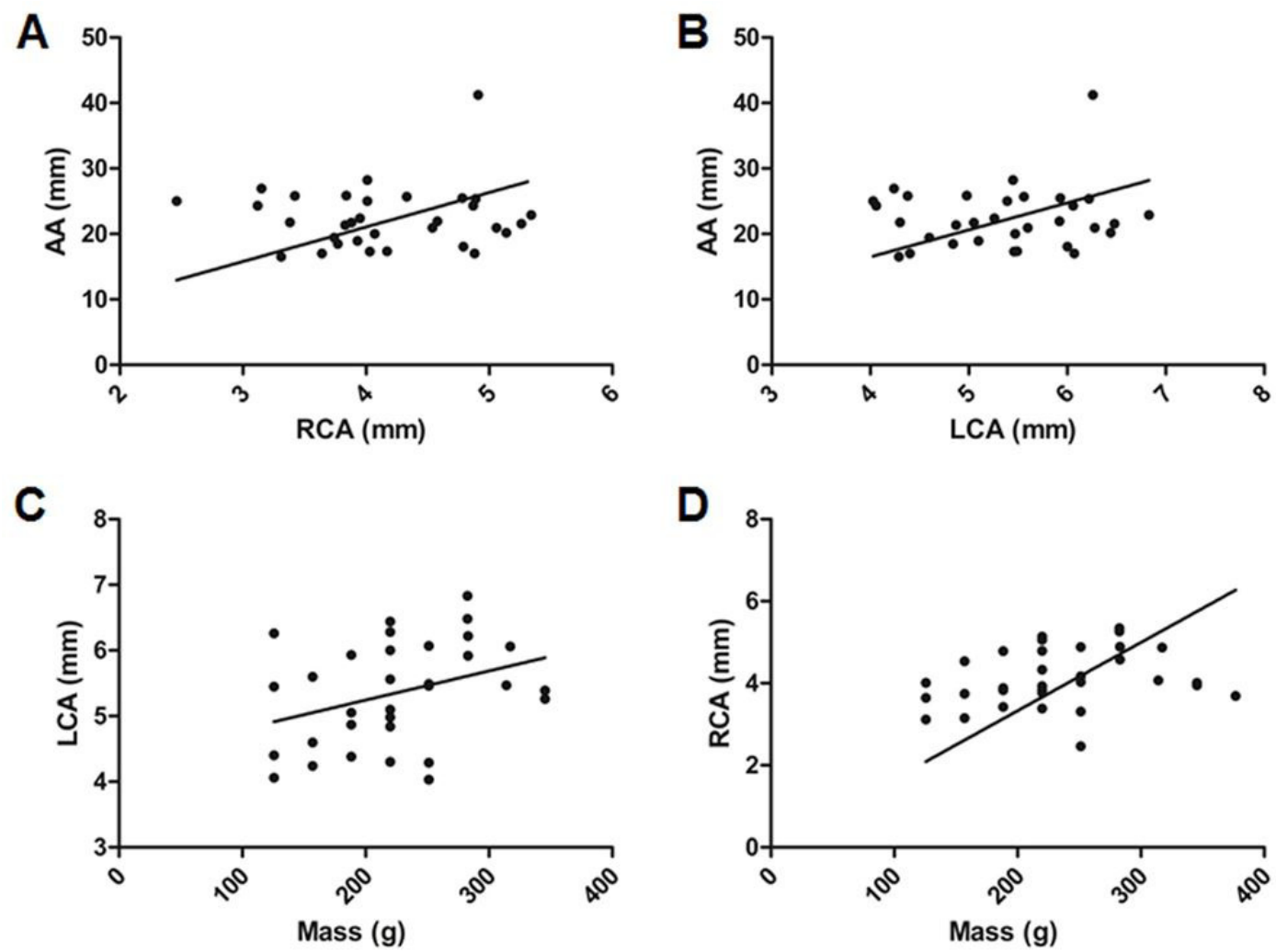

Figure 3. Correlation graphics of dissected human adult hearts $(n=39)$. Right coronary artery (RCA); Aorta artery (AA); left coronary artery (LCA). (A) Correlation of the external diameter of the RCA with AA. No Pearson correlation was observed, $\mathrm{r}=0.05986(p=0.7449)$. (B) Correlation of the external diameter of the LCA with AA. No Pearson correlation was observed, $\mathrm{r}=0.1170$ $(p=0.5325)$. (C) Correlation of the external diameter of the LCA with mass of hearts. Moderate positive Pearson correlation was observed, $\mathrm{r}=0.3505(p=0.0492)$. (D) Correlation of the external diameter of the RCA with mass of hearts. No Pearson correlation was observed, $\mathrm{r}=0.2557(p=0.1577)$.

The CAs originate from the aortic sinuses; the right CA arises from the anterior coronary sinus and the aortic sinus gives rise to the left CA, though there are variations in the anatomical location of the ostium and branching pattern. In this study, it was demonstrated that the external diameter of the LCA is approximately $22 \%$ greater than the external diameter of the RCA, resulting in a larger blood supply by the LCA, but also providing for a greater passage of atherosclerotic factors. This could hypothetically be beneficial in demonstrating that the LCA and its main branches, the anterior interventricular and circumflex, develop an occlusion process in $72.5 \%$ cases of acute myocardial infarction (JAMES, 1965), as illustrated by the differences between the external diameters of the CAs. First, the greater the number of nourished cardiomyocytes, the greater the coronary external diameter. Second, the LCA is responsible for nutrition to a large volume of the myocardium, including most of the left atrium (LA) and left ventricle (LV) (BEZERRA, NAGATO, VIEIRA et al., 2008). The LV is thicker and has the task of ejecting a quantity of blood throughout the body; thus, requiring a larger blood supply than the right ventricle. Moreover, the LCA is responsible for a considerable part of the right ventricle (REIG and PETIT, 2001). Considering the anatomical variations, Kalbfiesch and Hort (KALBFLEISCH and HORT, 1977) demonstrated that $63.8 \%$ of myocardial mass and $79 \%$ of the muscle mass of the left ventricle is irrigated by the LCA. Therefore, an obstruction of blood flow in the LCA would lead to more serious consequences than an obstruction in the RCA (REIG and PETIT, 2004).

The third hypothesis is related to the positioning of the origins of the coronary arteries. While the origin of the RCA does not suffer from any interference from adjacent structures (POURAFKARI, TABAN and GHAFFARI, 2014), the LCA originates among the pulmonary trunk and the left atrium (JAMES, 1965). Thus, evolutionarily, it is assumed that the larger external diameter of the LCA is compensatory since there are cases in which the increasing pressure in the pulmonary artery can cause an obstruction in the external diameter of the LCA. As a fourth hypothesis, the heightened caliber of the LCA branches compared with that of the RCA makes it necessary that the external diameter of the LCA be larger at its origin (DOUGLAS, FIOLKOSKI, BERKO et al., 1988). Data of the external diameter of the LCA obtained in this study were similar to data obtained in the study by Ortale, Meciano Filho, Paccola et al. (2005). Additionally, there were similarities not only in the predominance of obstruction in the branches of the LCA but also in the severity (AJAYI, LAZARUS, VANKER et al., 2013). As reported by Marino, Nascimento, Rabelo et al. (2012), in cases of acute MI, predominant stenosis was related to the LCA branches in $66.7 \%$ of cases, whereas, when we analyzed only the circumflex artery, the rate reached $88.23 \%$. 


\section{Conclusions}

Differences in the external diameters of the AA, RCA, and LCA are clinically relevant, since these vessels are responsible for nutrition of the body and heart. However, few studies correlated morphometric data and possible clinical complications related to $\mathrm{CAD}$.

Acknowledgements: The authors would like to express their appreciation to the anatomy department of University Severino Sombra (USS), Vassouras, Rio de Janeiro, this research was made possible due to the selfless gift from donor-cadaver-patients. Thank you.

\section{References}

AGUILA, MB., MANDARIM-DE-LACERDA, CA. and APFEL, MI. Stereology of the myocardium in young and aged rats. Arquivos Brasileiros de Cardiologia, 1998, vol. 70, n. 2, p. 105-109. PMid:9659717.

AJAYI, NO., LAZARUS, L., VANKER, EA. and SATYAPAL, KS. The impact of left main coronary artery morphology on the distribution of atherosclerotic lesions in its branches. Folia Morphologica, 2013, vol. 72, n. 3, p. 197-201. PMid:24068680. http://dx.doi.org/10.5603/ FM.2013.0033.

BEZERRA, FS., NAGATO, AC., VIEIRA, CLJ., REIS, LA., NOVAIS, L. and VALENÇA, SS. Study of sinoatrial nodal artery dominance in Brazilian human hearts. International Journal of Morphology, 2008, vol. 26, p. 47-50.

DOUGLAS, PS., FIOLKOSKI, J., BERKO, B. and REICHEK, N. Echocardiographic visualization of coronary artery anatomy in the adult. Journal of the American College of Cardiology, 1988, vol. 11, n. 3, p. 565-571. PMid:3343459. http://dx.doi.org/10.1016/07351097(88)91532-X.

GO, AS., MOZAFFARIAN, D., ROGER, VL., BENJAMIN, EJ., BERRY, JD., BLAHA, MJ., DAI, S., FORD, ES., FOX, CS., FRANCO, S., FULLERTON, HJ., GILLESPIE, C., HAILPERN, SM., HEIT, JA., HOWARD, VJ., HUFFMAN, MD., JUDD, SE., KISSELA, BM., KITTNER, SJ., LACKLAND, DT., LICHTMAN, JH., LISABETH, LD., MACKEY, RH., MAGID, DJ., MARCUS, GM., MARELLI, A., MATCHAR, DB., MCGUIRE, DK., MOHLER 3RD, ER, MOY, CS., MUSSOLINO, ME., NEUMAR, RW., NICHOL, G., PANDEY, DK., PAYNTER, NP., REEVES, MJ., SORLIE, PD., STEIN, J., TOWFIGHI, A., TURAN, TN., VIRANI, SS., WONG, ND., WOO, D. and TURNER, MB. Heart disease and stroke statistics - 2014 update: a report from the American Heart Association. Circulation, 2014, vol. 129, n. 3, p. e28-e292. PMid:24352519. http://dx.doi. org/10.1161/01.cir.0000441139.02102.80.

JAMES, TN. Anatomy of the coronary arteries in health and disease. Circulation, 1965, vol. 32, n. 6, p. 1020-1033. PMid:5846099. http://dx.doi.org/10.1161/01.CIR.32.6.1020.

KALBFLEISCH, H. and HORT, W. Quantitative study on the size of coronary artery supplying areas postmortem. American Heart Journal, 1977, vol. 94, n. 2, p. 183-188. PMid:141876. http:// dx.doi.org/10.1016/S0002-8703(77)80278-0.

LOUKAS, M., GROAT, C., KHANGURA, R., OWENS, DG. and ANDERSON, RH. The normal and abnormal anatomy of the coronary arteries. Clinical Anatomy, 2009, vol. 22, n. 1, p. 114-128. PMid:19097062. http://dx.doi.org/10.1002/ca.20761.

MADJID, M. and FATEMI, O. Components of the complete blood count as risk predictors for coronary heart disease: in-depth review and update. Texas Heart Institute Journal, 2013, vol. 40, n. 1, p. 17-29. PMid:23467296.

MARINO, BCA., NASCIMENTO, GA., RABELO, W., MARINO, MA. and MARINO, RL. Infarto do miocárdio sem supradesnivelamento do segmento ST: características clínicas, angiográficas e evolução intra-hospitalar dos pacientes. Revista Médica de Minas Gerais, 2012, vol. 22 , p. 53-58.
MAUROVICH-HORVAT, P., FERENCIK, M., VOROS, S., MERKELY, B. and HOFFMANN, U. Comprehensive plaque assessment by coronary CT angiography. Nature Reviews. Cardiology, 2014, vol. 11, n. 7, p. 390-402. PMid:24755916. http://dx.doi. org/10.1038/nrcardio.2014.60.

MCCULLOUGH, PA. Coronary artery disease. Clinical Journal of the American Society of Nephrology, 2007, vol. 2, n. 3, p. 611-616. PMid:17699471. http://dx.doi.org/10.2215/CJN.03871106.

MYERS, L. and MENDIS, S. Cardiovascular disease research output in WHO priority areas between 2002 and 2011. Journal of Epidemiology and Global Health, 2014, vol. 4, n. 1, p. 23-28. PMid:24534332. http://dx.doi.org/10.1016/j.jegh.2013.09.007.

NORDON, D. and RODRIGUES JÚNIOR, O. Variations in the anatomy of the coronary arteries. Journal of Morphological Science, 2012, vol. 29 , n. 3, p. 178-181

NORIEGA, FJ., VIVES-BORRÁS, M., SOLÉ-GONZÁLEZ, E., GARCÍA-PICART, J., ARZAMENDI, D. and CINCA, J. Influence of the extent of coronary atherosclerotic disease on ST-segment changes induced by ST elevation myocardial infarction. The American Journal of Cardiology, 2014, vol. 113, n. 5, p. 757-764. PMid:24406107. http://dx.doi.org/10.1016/j.amjcard.2013.11.034.

ORTALE, JR., MECIANO FILHO, J., PACCOLA, AMF., LEAL, JGPG. and SCARANARI, CA. Anatomy of the lateral, diagonal and anterosuperior arterial branches of the left ventricle of the human heart. Revista Brasileira de Cirurgia Cardiovascular, 2005, vol. 20, p. 10. http://dx.doi.org/10.1590/S0102-76382005000200010.

POURAFKARI, L., TABAN, M. and GHAFFARI, S. Anomalous origin of right coronary artery from distal left circumflex artery: a case study and a review of its clinical significance. Journal of Cardiovascular and Thoracic Research, 2014, vol. 6, n. 2, p. 127-130. http://dx.doi. org/10.5681/jcvtr.2014.027. PMid:25031830.

REIG, J. and PETIT, M. Perfusion of myocardial segments of the right ventricle: role of the left coronary artery in infarction of the right ventricle. Clinical Anatomy, 2001, vol. 14, n. 2, p. 142-148. PMid:11241749. http://dx.doi.org/10.1002/1098-2353(200103)14:2<142::AIDCAl022>3.0.CO $; 2-\mathrm{H}$.

REIG, J. and PETIT, M. Main trunk of the left coronary artery: anatomic study of the parameters of clinical interest. Clinical Anatomy, 2004, vol. 17, n. 1, p. 6-13. PMid:14695580. http:// dx.doi.org/10.1002/ca.10162.

TAYLOR, CJ. and HOBBS, FD. Heart failure therapy in patients with coronary artery disease. Current Opinion in Pharmacology, 2013, vol. 13, n. 2, p. 205-209. PMid:23540585. http://dx.doi. org/10.1016/j.coph.2013.01.009.

TERESA ALBELDA, M., GARCIA-ESPANA, E. and FRIAS, JC. Visualizing the atherosclerotic plaque: a chemical perspective. Chemical Society Reviews, 2014, vol. 43, n. 8, p. 2858-2876. PMid:24526041. http://dx.doi.org/10.1039/c3cs60410a.

TULLOH, RM. and WOOD, LE. Coronary artery changes in patients with Kawasaki disease. Acta Paediatrica, 2004, vol. 93, Supplement, n. 446 , p. $75-79$.

WONG, ND. Epidemiological studies of CHD and the evolution of preventive cardiology. Nature Reviews. Cardiology, 2014, vol. 11, n. 5, p. 276-289. PMid:24663092. http://dx.doi.org/10.1038/ nrcardio.2014.26.

YIN, G., HASSAN, F., HAROUN, AR., MURPHY, LL., CROTTI, L., SCHWARTZ, PJ., GEORGE, AL. and SATIN, J. Arrhythmogenic calmodulin mutations disrupt intracellular cardiomyocyte Ca2+ regulation by distinct mechanisms. Journal of the American Heart Association, 2014, vol. 3, n. 3, p. e000996. PMid:24958779. http:// dx.doi.org/10.1161/JAHA.114.000996.

Received September 1, 2015 Accepted 8 November 8, 2016 